\title{
The Oppression of Ukrainian National Identity by the Soviet Mass Media: Political and Ideological Censorship 60's and 70's of the Twentieth Century
}

\author{
Dławienie ukraińskiej tożsamości narodowej przez radzieckie środki masowego \\ przekazu: cenzura polityczna i ideologiczna w latach 60. i 70. XX wieku
}

\section{- Abstrakt •}

Artykuł ten opisuje dławienie ukraińskiej tożsamości narodowej przez radzieckie środki masowego przekazu, które służyły jako narzędzie ideologiczne komunistycznych władz pomocne w osiągnięciu celu całkowitej rusyfikacji i denacjonalizacji Ukraińców w latach 60. i 70. XX wieku. Stosowana wtedy cenzura analizowana jest jako jedna z metod nadzoru państwa nad treściami rozpowszechnianymi przez środki masowego przekazu w celu ograniczenia szerzenia się idei i informacji uznanych przez ówczesne władze za „niepożądane” lub „szkodliwe ideologicznie". Artykuł naświetla destrukcyjną rolę środków masowego przekazu w zawężaniu narodowego światopoglądu Ukraińców, skutki prześladowania presay ukraińskojęzycznej oraz tłamszenia aspektu narodowego w ukraińskim środowisku etnicznym w tym okresie.

Słowa kluczowe: ukraińskie środowisko etniczne; świadomość narodowa; media masowe; cenzura polityczna; władza radziecka; reżim totalitarny; propaganda komunistyczna; ideologiczny ucisk; denacjonalizacja

\section{- Abstract •}

This article covers the oppression of Ukrainian national identity by the Soviet mass media, which served as an ideological tool of the communist government on the way of total russification and denationalization of Ukrainians over the 60's and 70's of the $20^{\text {th }}$ century; censorship is being studied as one of the methods of state supervision over the control of the release of the mass media in order to restrict the dissemination of the ideas and information that were recognized by the then authorities as "undesirable" or "ideologically harmful". The destructive role of the mass media in the narrowing of the national worldview of Ukrainians, the prohibition of the Ukrainian word, and the leveling of the national aspect in the Ukrainian ethnic environment in the defined period are highlighted.

Keywords: Ukrainian ethnic environment; national consciousness; the mass media; political censorship; the Soviet power; the totalitarian regime; the communist propaganda; an ideological oppression; denationalization 


\section{Formulation of the Research Problem and Its Significance}

In today's conditions of development of the Ukrainian society, successful accomplishment of tasks in the political, economic, cultural and educational sphere increasingly depends on social activity of individuals, an important role in the formation of which is played by the media. Reaching wide audiences, the media have exceptionally large influence on the state of public consciousness, including the formation of a national outlook as an important factor in state-building processes in Ukraine. However, the media can also play a destructive role, in particular, contribute to subversion of centuries-old national values of the people. This tendency was clearly observed in the Soviet era - a long period of Ukrainian non-statehood, when the information field was politically biased, with the media message clearly predictable and consistent exclusively with the ideals of the CPSU - KPU.

With the achievement of Ukraine's independence and democratization of the socio-political life, including the opened access to many archival sources, favorable conditions were created for a free, unbiased, methodologically weighed study of the Soviet past of the Ukrainian people. Such study would allow for expansion of the field of national memory and historical consciousness of citizens as a result of access to previously neglected information about the past. It was the time to re-frame and consider once more the events that have dramatically affected the historical progress and revival of the Ukrainian nation. Reconsideration of a number of issues in national history related to aspirations of the Ukrainian people to state independence became a key goal. Therefore, the question of a comprehensive study of the media as an ideological tool of the Soviet power in implementing the policy of denationalization of Ukrainians during the 1960's and 1970's is extremely relevant and requires special study.

\section{State of Research on the Topic}

The question of role of the media in the life of the Ukrainian people in the Soviet period is partly covered in the writings of such authors as: Vitali Vovk (2008), Yuri Kalganov (2014), Victoria Karlova (2007), Yuri Kolisnik (2011), Ivan Krupsky (2014), Oksana Fedotova (2012), Murat Hadji (2013) and others. Only some aspects of this topic were discussed in scholarly literature however, in particular: dominance of political censorship in the information space of the Ukrainian SSR, regionality issues in the media, definition of function of the Soviet press in the implementation of national economic and socio-cultural plans for the develop- 
ment of the country on its path to building a communist society, issue of politico-ideological control over printed media, etc. However, in scientific literature the research subject selected by the author has remained insufficiently studied, what gave rise to the opportunity to continue research work in this interesting direction.

\section{Aim of the Article}

Thus, the focus of this article is the study of the media as an ideological weapon of the Soviet power in destroying the national identity of Ukrainians during the 1960's-1970's. The analysis covers the influence of the media in creation of a system of ideological notions and values supporting the Soviet totalitarian state among the society, a showing of the political bias of the media scene in the Ukrainian SSR, and a study of mass media functioning as an important mechanism for implementing the policy of russification and combating the manifestations of self-determination aspirations of Ukrainians.

\section{Main Material and Justification of Study Results}

Mass media traditionally held leadership as concerns ideological influence on society and individuals. Realizing this fact, the Soviet authorities actively used this function of the media to propagate their political interests and manipulate the mass public consciousness of Ukrainians. Mass media during the 1960's and 1970's became a reflection of and a standard-bearer of the then socio-political system. The media created, regulated and directed a certain stream of information compliant with the message of the CPSU - KPU. In such a situation, the national identity and historical memory of the Ukrainian nation were lost and the skill and the need to think critically were eliminated, what led to emergence of generations unable to stand alone and formulate their own ideas.

Since 1959, the output of the Ukrainian printed media is decreasing, while the number of Russian-speaking media outlets continues to grow. While Ukrainians constituted $17 \%$ of the population of the USSR, only $4,3 \%$ of the relevant publications were Ukrainian-language productions (Vovk, 2007). The most interesting and most important reports and news were covered in Russian-language publications, while the Ukrainian-speaking press often had to cover minor and uninteresting topics devoted to the construction of socialism. This situation led to loss of the readers' interest and, consequently, the circulation of the Ukrainian 
printed word was further reduced, which, in turn, became a convenient reason for complete closure of Ukrainian publishing houses. Ukrainian-language publications were in demand in the western regions of the republic and in the countryside (Kalganov, 2014).

With the coming to power of V. Shcherbytsky, the Ukrainian printed word suffered an even more devastating blow than in previous years. Everything Ukrainian was purposefully destroyed. Ideologization, denationalization and russification intensified, which significantly narrowed the sphere of applications of the Ukrainian language and contributed to the image of its inferiority. Thus in the 1970's the share of Ukrainian-language magazines in the Ukrainian SSR decreased from $46 \%$ to 19\% (Yekelchik, 2011). Ukrainian-language newspapers and magazines in Poland and Czechoslovakia, where a large Ukrainian diaspora lived, covered on their pages the issue of discrimination of this national language. For example, the magazine Our Culture, published in Warsaw, informing its readers of the First All-Slavonic Archaeological Congress (September 1965, Warsaw) stated: "It was nice to hear the speeches at the Congress delivered in languages of not only large Slavic peoples, but also of smaller ones like Bulgarians, Croats, Slovaks... Among all the peoples represented at the Congress, only Ukrainians delivered all lectures not in their native language, but in Russian" (Kalganov, 2014). Another example of oppression of the Ukrainian language was the criticism of the magazine Vsesvit for publishing a Ukrainian translation of one of foreign works that had been previously translated and published in Russian. In view of this, the magazine's editor-in-chief $O$. Poltoratsky issued a regulation which prohibited the translation into Ukrainian of foreign works that had already been published in Russian (Baran, Danilenko, 1999).

It should also be noted that a significant part of the Ukrainian printed word was of poor quality, since only $1 \%$ of all Ukrainian-language output was published by printing companies with a state-level mark of quality (Vovk, 2007). However, only the readers were concerned with such a situation, as the State Committee of the USSR even in the late 1970's did not implement any additional measures to improve the technical level and quality of products at the enterprises under its control (From the Minutes of Meetings of the UMR RS, 1977). In addition, the financial conditions of employment at Ukrainian-language printers were significantly worse than those in Russian-speaking publications. For example, the remuneration of the editor-in-chief of the magazine Motherland in the period under study amounted to 1500 rubles, while the editor-in-chief of the (Russian-speaking) journal October earned 6,000 rubles (Kalganov, 2014). A similar situation was noted by the member of the Council for Ukrainian Literature at the Union of 
Writers of the USSR F. Kravchenko: "The responsible secretary of the Ukrainian republican magazine receives 120 rubles per month, and the responsible secretary of the Russian regionals (Don, Podyom) -180 rubles. Why? It's impossible to explain! (...) And outside our country all this is noticed and some persons do 'politics' on it (...). Recently, Voice of America stated that the difference in payment for journalism is explained, they say, by all the same reasons: Ukrainians are being looked at as less valuable employees" (Kalganov, 2014).

The Soviet mass media constantly exploited and at the same time preserved a set of stereotypes and flagship beliefs, among them: the idea of inviolable unity of the "Soviet peoples", the care and concern of the communist party for the working people, priority of the collective over the individual, and others. Topics that concerned national issues did not have the chance to appear on the pages of newspapers, as censorship was severe. The state-dependent status of the Ukrainian press was manifested for example in the functioning of the Radiotelegraph Agency of Ukraine (RATAU). Concerned about this, the editorial office of the Zakarpatskaya Pravda newspaper stated: "One can immediately say that RATAU does not have its own national face (...). What RATAU is doing has put its newspapers in Ukrainian into secondary positions. (...) the agency transmits all the official news and documents in Russian several hours earlier than in Ukrainian, and this sometimes causes a delay in publication of the Ukrainian newspapers (...). Very often RATAU broadcasts materials with a memorandum 'only in Russian'”. (Kalganov, 2014).

There was also a category of citizens who skeptically perceived all information provided by the Soviet media, and therefore with great interest became followers of samizdat, underground news outlets. During the period under study, the following underground works were especially popular among the readers: Internationalism or Russification? by I. Dzyuba, Woe from Wit (Portraits of Twenty Criminals) by V. Chornovil, The State and Problems of the Ukrainian Liberation Movement of E. Pronyuka. Popular were also the works of many historians who disagreed with the official Soviet historiography and had opposing views on a number of historical facts and events (Baran, Danilenko, 1999). However, an active offensive campaign against the rights and freedoms of the people in the Ukrainian SSR led to increased attention of the controlling authorities, discovery of such "nationalist" works and active search for products of samizdat as undesirable. Under such conditions, censorship agencies helped the political control bodies in monitoring the work of dissidents and political emigrants. The works of those who "compromised" themselves in the eyes of the Soviet authorities were withdrawn from circulation as "harmful", "imperfect" and "ideologically false". The head of the Ukrainian SSR even appealed to the Central Committee of the Communist Party in 1979 
with a request to issue instructions to the relevant authorities about informing the censorship agencies of any departure from the country of persons whose anti-Soviet activities abroad could harm the interests of the USSR (Fedotova, 2012).

An important role in the process of denationalization and ideologization of the Ukrainian nation in the Ukrainian SSR during the 1960s and 1970's was played by the Soviet television. In November 1952, the first television centre in Ukraine began its work in Kyiv; later branches began operations in Kharkiv and Donetsk. It should be noted that the production of Soviet television was also under close control of the state and of communist bodies; television studios were able to disseminate only information that corresponded to the Soviet political and social ideology - in other words, they transmitted mass propaganda rooted in the ideological foundations of the CPSU - CPU, thereby brainwashing the population. Thus television concerts almost always started with songs about V. Lenin and the Communist Party: Praise of the Communist Party, With the Name of Lenin, March of the Brigades of Communist Labor etc. (Kasimenk, 1960). Representatives of the Communist Party, who sought to eliminate all national differences within the Ukrainian SSR extolled the notions of "united Soviet people" and "dominant" Russia, and has quite significant screen time over that period.

As a means of denationalization and ideologization of the titular nation of the Ukrainian SSR, the Soviet authorities actively used radio, as about $90 \%$ of Ukrainians listened daily to radio broadcasts (Zhuravlyov, 1979). In particular, the local radio gave much of its air time to broadcasts from Moscow, which were conducted only in Russian; all other programs were also mostly in Russian (Dziuba, 2005). The state organs of the Ukrainian SSR decided what the audience should listen to on the radio and what they should not. An example from the 1970's is a broadcast of a concert from the Great Hall of the Moscow Conservatory on the All-Union Radio, which in its programme included Ukrainian Christmas carols. The concert was broadcast only until the carols were scheduled to start, at that point the transmission was turned off (Demidenko, 1993). The public authorities of the Ukrainian SSR exerted a heavy pressure on radio workers and ensured that there was no "ideological inconsistencies and political mistakes" (Information of the CPU Regional Committees, 1959). As a rule, all materials of radio broadcasts were read by the editor-in-chief, and those relating to "particularly important issues" were reviewed also by the Propaganda and Agitation Department of the Regional Committee of the CPU covering the relevant domain (Information of the CPU Regional Committees, 1959).

A peculiar informational revolution at that time was carried out by the US with the help of their radio station Voice of America (about 62 broadcasts per 
day), which was made available in many languages of the peoples of the USSR (Afanasyeva, Afiani, 2000). Popular sources of political information were also the radio stations: BBC, Radio Vatican, Canada, Madrid, Rome, Liberty and others (The References of the Departments of the Central Committee, 1960). Soviet ideologists tried to reduce the impact of these "harmful" programs, forbidding citizens to listen to them, as prescribed in the resolution of the ideological commission of the Central Committee of the CPSU "On the fight against hostile radio propaganda" on January 16, 1959 (Afanasyeva, Afiani, 2000). However, thanks to the imported or "self-improved" radio receivers, Ukrainians secretly had access to information opposing the official political line (The References of the de Dpartments of the Central Committee, 1960).

\section{Conclusions}

Consequently, based on the foregoing, one can draw the conclusion that the mass media became ideological tools of the Soviet power in its aim to destroy the national identity of Ukrainians during the 1960's and 1970's. Censorship was an important component of the totalitarian state policy and, by excising "politically harmful" information the authorities effectively created the desired ideological and values model in the information space of the Ukrainian SSR. The key principles in play were: strict control over the ideological and political content of printed publications as well as radio and television broadcasts, no tolerance for alternative judgments, ban on criticism of communist ideology and practices, elimination of national ideals and manifestations of "national fanaticism", downplaying of national sentiment and political-ideological harassment of Ukrainians. The media participated daily in the party myth-making, consolidating the socialist outlook on life, propagating Soviet way of life and patriotism. These elements were aimed against awakening of the national consciousness of Ukrainians and the practical realization of their aspiration for national separation and self-determination. In addition, the Communist Party leadership tried to minimize the use of the Ukrainian language, and, using the media, actively implemented the policy of russification.

\section{References:}

Afanasyeva, E.S., Afiani, V.Yu. (2000). Ideological Commission of the Central Committee of the CPSU. 1958-1964: Documents. Moscow: Russian Political Ethics. 
Baran, V.K., Danilenko, V.M. (1999). Ukraine in the Conditions of the Systemic Crisis (1946-1980's). Kyiv: Alternatives.

Dziuba, I. (2005). Internationalism or Russification?. Kyiv: Kyiv-Mohyla Academy.

Demidenko, T. (1993). Party and State Policy in the Field of Culture in the 70's (On the Example of Ukraine and Byelorussia). In: Ukraine XX Century: Culture, Ideology, Politics: A Collection of Articles (p. 180-188). Kyiv: Institute of History of the National Academy of Sciences of Ukraine.

Fedotova, O. (2012). Political Censorship in the USSR - USSR: Practice of Restricting Printed Products. Journal of the Book Chamber, 2, 1-3.

From the Minutes of Meetings of the UMR RS of the Republic of Moldova "On Measures for the Further Improvement of Housing and Living Conditions, Medical Care and Improvement of Public Education Workers and Materials to It". (1977). Fund. 2. Description. 14. Case 1134. Kyiv: Central State Archive of the Supreme Power and Administration of Ukraine.

The References of the Departments of the Central Committee of the Communist Party of Ukraine, the Letters of the Regional Committees of the Communist Party of Ukraine and Other Organizations on Anti-Soviet Manifestations and the Struggle Against Them (Commenced on February 10, 1960, on October 7, 1960). (1960). Fund. 1. Description. 24. Case 5141. Kyiv: Central State Archive of Public Associations of Ukraine.

Information of the CPU Regional Committees on the Progress in Implementing the Decree of the Central Committee of the CPU "On the Facts of Irresponsible Attitude Towards the Preparation of Radio Programs”. (1959). Fund. 1. Description. 70. Case 2421. Kyiv: Central State Archive of Public Associations of Ukraine.

Kalganov, Yu.O. (2014). Soviet Press and the Construction of Mass Public Consciousness in Ukraine (1950s-1985s). Scientific Papers of the Historical Faculty of Zaporizhzhya National University, XXXVIII, 213-225.

Karlova, V.V. (2007). The Influence of Mass Media on the Formation of Ukrainian National Consciousness. Public Administration: Theory and Practice, 2.

Kasimenk, O.K. (1960). History of Kyiv. Kyiv: Institute of History of the Academy of Sciences of the Ukrainian SSR.

Khadzha, M. (2013). The Role of Media in the Association of the Nation of a Country in the Transitional Period. Scientific Notes of the Institute of Journalism, 51 (April-June), 190-193.

Kolisnyk, Yu. (2011). The Dominance of Political Censorship in the Information Space of the Ukrainian SSR. Visnyk of Lviv University, 35, 167-181.

Krupsky, I. (2014). The Topics of Mass Media of Ukraine - An Important Part of the Information Space of the State (For Example, Western Ukrainian lands of 1944-1950's). Tele and Radio Journalism, 13, 96-103.

Vovk, V.M. (2007). Life and Leisure of the Urban Population of Ukraine in the 50's and 80's of the Twentieth Century. Kiev: Pereyaslav-Khmelnytsky State Pedagogical University named after Gregory Skovoroda.

Yekelchik, S. (2011). History of Ukraine. Birth of the Modern Nation. Kyiv: Laurus. Zhuravlyov, G. (1979). Youth Leisure Time. Moscow: Knowledge. 